\title{
48. GEOTECHNICAL AND LOGGING EVIDENCE FOR UNDERCONSOLIDATION OF LAU BASIN SEDIMENTS: RAPID SEDIMENTATION VS. FLUID FLOW ${ }^{1}$
}

\author{
Dawn L. Lavoie, ${ }^{2}$ Terry R. Bruns, ${ }^{3}$ and Kathleen M. Fischer ${ }^{2}$
}

\begin{abstract}
We analyzed geotechnical and acoustic properties of sediments from Lau Basin backarc Sites 834, 835, 838, and 839 to examine the large-scale heat and fluid circulation in the Lau Basin. We hypothesize that a feedback system exists in which sediment properties, particularly permeability, affect large-scale heat and fluid circulation and are, in turn, affected by the circulation of fluids.

Sediments in the Lau backarc basin display none of the expected trends in physical and acoustic properties as a function of depth and are probably underconsolidated. The sediments can consolidate normally, however, as shown by measuring both compressional- and shear-wave velocity in a controlled laboratory triaxial setting. In-situ underconsolidation might occur because high sedimentation rates could prevent the sediments from dewatering and consolidating normally, or water lost during the consolidation process could be rapidly replaced by fluids circulating through the system convectively.

Although initial sedimentation rates were extremely high in the Lau Basin, laboratory measurements indicate that the overlying clayey nannofossil oozes are sufficiently permeable to allow the passage of fluids through the sediments on the scale of several years; however, a comparison of vertical and horizontal components of flow indicates that horizontal fluid flow is 3 orders of magnitude greater than vertical flow. The highly permeable vitric silts and sands probably dominate the horizontal component of fluid flow.

Measured vertical heat flow at these sites is much lower than would be predicted by a simple cooling model, suggesting that heat is flowing laterally. A large difference in measured heat flow exists between the lowermost stratigraphic units of Sites 834 and 835 , indicating that lateral fluid flow may be occurring. The chemistry of pore fluids measured at Sites 834,835 , and 838 shows an increase and subsequent decrease in dissolved calcium with depth within the sediment column, again suggesting lateral fluid flow. The dissolved-calcium profile at Site 839 shows a seawater signature and no consistent trend downhole, indicating possible downwelling of bottom water throughout the entire sediment column.

The volume of fluid required to (1) dissipate the excess heat expected but not measured and (2) prevent the sediments from consolidating normally in these Lau backarc sites is very small, about $8 \mathrm{~m}^{3}$ at Site 834 . Very small gradients are required to replace this amount of fluid lost during the $5.5 \mathrm{~m} . \mathrm{y}$. of sediment deposition. In general, sites of downwelling are much more diffuse and cooler than sites of upwelling. Site 839 probably is a downwelling site. The remaining three sites possibly are located in a zone of lateral fluid flow within a large-scale, convective circulation cell.
\end{abstract}

\section{INTRODUCTION}

Physical and acoustic properties of marine sediments are indicators of large-scale geological processes taking place in situ. For example, heat and fluid exchange between seawater and basalt basement occurs easily when basalt is either exposed or covered with a thin veneer of sediment (Louden and Wright, 1988). However, as the sediment cover thickens and sediments become less permeable, convective heat and fluid exchange between basalt and seawater diminishes. The permeability, or ease of fluid flow, through the sediment limits convective seawater circulation and controls the rate of dewatering of the sediment and, therefore, the amount of consolidation that occurs. Anumber of sediment properties, including permeability, index properties, shear strength, and compressional- and shear-wave velocity, are dependent on the consolidation state of the sediment. We hypothesize that a feedback system exists in which sediment properties, particularly permeability, affect large-scale circulation and are, in turn, affected by the circulation of fluid.

The objective of this paper is to present analyses of the geotechnical and acoustic sediment properties of Lau backarc Sites 834, 835, 838 , and 839; and, from these results, to infer something about the effects of fluid flow on larger scale geological processes occurring in the Lau Basin. In normally consolidated sedimentary sequences, properties such as density and velocity increase with depth, and other

\footnotetext{
'Hawkins, J., Parson, L., Allan, J., et al., 1994. Proc. ODP, Sci. Results, 135: College Station, TX (Ocean Drilling Program).

${ }^{2}$ Naval Research Laboratory, Code 7431, Stennis Space Center, MS 39529, U.S.A.

${ }^{3}$ U.S. Geological Survey, Branch of Pacific Marine Geology, 345 Middlefield Road, Menlo Park, CA 94025 , U.S.A.
}

properties such as porosity and water content decrease with depth. An unexpected finding in the backarc sites was that physical properties gradients within the sediments overlying basalt, particularly at Sites 834 and 835 , were negligible. The variations observed in the physical properties measurements were related to distinct changes in lithology. One result of this interpretation of the physical properties values is that high fluid flow through the sediments may explain why normal gradients in physical properties were not found, that is, may explain the underlying reason for the lack of consolidation in the sedimentary column in the backarc basin.

\section{Background}

The Lau backarc basin is characterized by a number of small sedimented basins and bedrock highs formed as horsts and grabens. Sites 834 and 835 were drilled during Ocean Drilling Program (ODP) Leg 135 in two separate sub-basins $48 \mathrm{~km}$ apart, part of a north-trending basin with $200-400 \mathrm{~m}$ of relief, approximately $100 \mathrm{~km}$ east of the Lau Ridge and $80 \mathrm{~km}$ west of the Central Lau Spreading Center (CLSC; Fig. 1). Water depths at Sites 834 and 835 are 2692 and $2916 \mathrm{~m}$, respectively. Sites 838 and 839 lie in the same basin in 2617 and 2322 $\mathrm{m}$ of water, but they are separated by a flexure that forms a low ridge of $400-600 \mathrm{~m}$ relief, approximately $55 \mathrm{~km}$ west of the East Lau Spreading Center (ELSC) and about $200 \mathrm{~km}$ east of the Lau Ridge axis.

The total sediment thickness is $106 \mathrm{~m}$ at Site $834,155 \mathrm{~m}$ at Site $835,103 \mathrm{~m}$ at Site 838, and $100 \mathrm{~m}$ at Site 839. Scientists on Leg 135 found that a significant contribution to the sediments came from Lau Ridge and intrabasin volcanic constructions from mid-Miocene to mid-Pliocene time (Parson, Hawkins, Allan, et al., 1992). The minimum basement ages of Sites 834 and 835 are 5.6 and $3.5 \mathrm{Ma}$, re- 


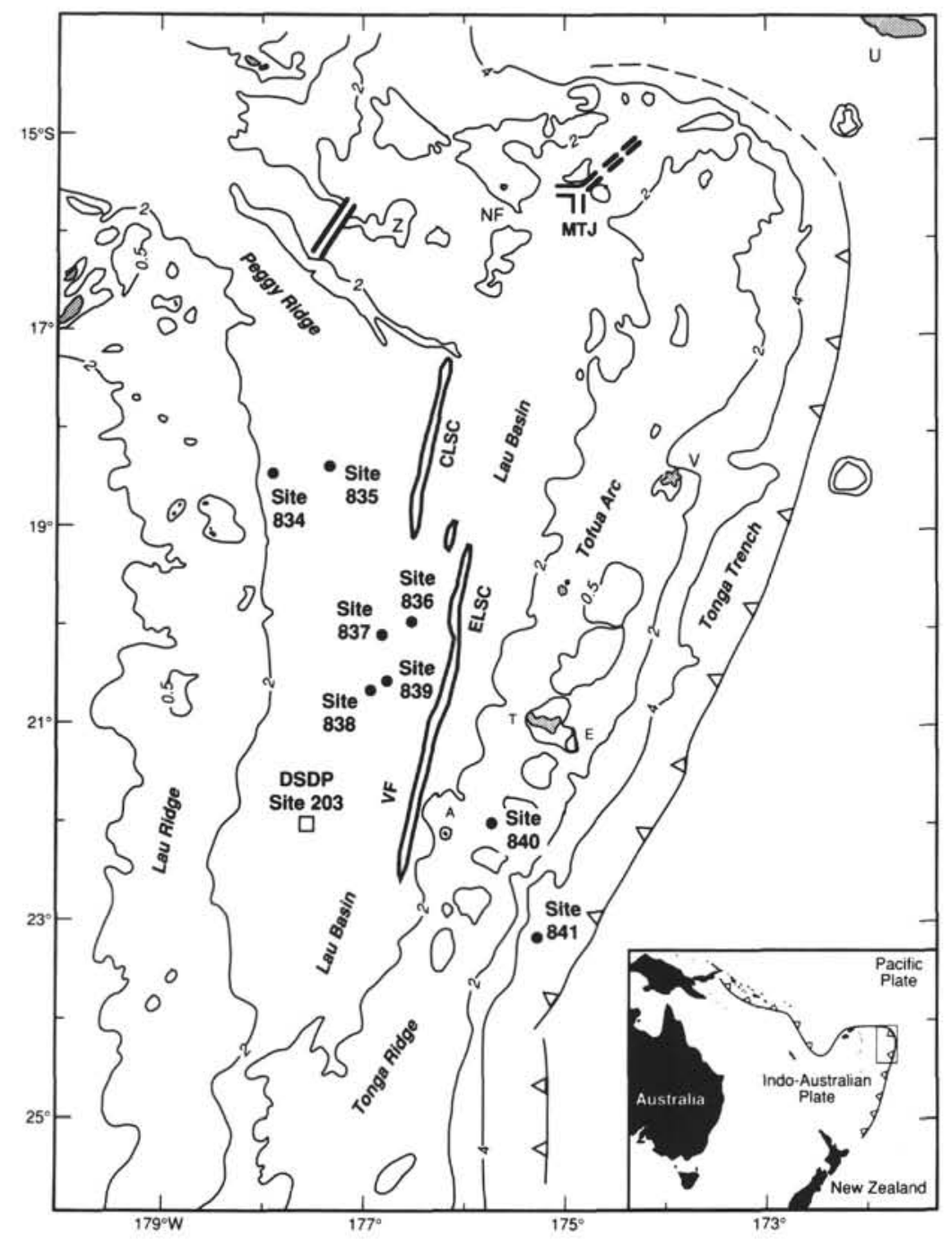

Figure 1. Bathymetric map of the Lau Basin area showing the locations of Sites 834. 835.838. and 839. Redrawn from Parson, Hawkins, Allan, et al. (1992). Central Lau (CLSC) and Eastern Lau (ELSC) spreading centers, Valu Fa (VF) Ridge, Tonga Trench, and Mangatolu Triple Junction (MTJ) are shown for reference. Contour intervals in kilometers.

spectively. The age of basement at Site 838 is at least $3 \mathrm{Ma}$, and at Site $839,1.7 \mathrm{Ma}$. The sedimentation rates were extremely high during periods of intense volcanic activity from the late Miocene to the late Pliocene, up to $383 \mathrm{~mm} / \mathrm{k}$.y. at Site 834 and $882 \mathrm{~mm} / \mathrm{k}$.y. at Site 839 , when basalts and thick vitric ash beds were deposited. The cessation of volcanism at all sites was followed by an influx of volcanic silt, sand, and gravels; sedimentation rates were lower from this period during the late Pliocene to the Quaternary, between 38 and $9 \mathrm{~mm} / \mathrm{k} . \mathrm{y}$.

The sediments found at the four sites are predominantly clayey nannofossil oozes, clayey nannofossil mixed sediments, and volcanic silts and sands. Modes of deposition were pelagic, turbiditic, and debris flows. The volcaniclastic sediments are mainly epiclastic and predominantly mass-flow deposits (e.g., turbidites). The larger size fraction is composed of fibrous pumice shards with elongated tubular vesicles. All are enriched with vitric shards.

\section{METHODS}

Physical properties analyses made on board the JOIDES Resolution include gamma-ray attenuation porosity evaluator (GRAPE) density measurements; $P$-wave logger compressional-wave velocity measure- ments; index properties measurements, including water content, porosity, void ratio, and wet-bulk density; thermal conductivity and downhole temperature measurements using the ODP temperature probe; and compressional-wave velocity measurements using the Hamilton Frame device. These measurements, with the exception of the downhole temperature measurements, were made at ambient laboratory pressures after the cores had equilibrated (Parson, Hawkins, Allan, et al., 1992, pp. 49-79).

Onshore, eight samples from Sites 834, 835, 838, and 839 were reconsolidated to estimated in-situ pressures in a triaxial apparatus in which the stresses in all three planes could be controlled. Compressional-and shear-wave velocities were measured continuously during the process of consolidation. Permeability was measured after primary consolidation was complete by using a constant-head permeability technique (Lambe, 1951). The samples were consolidated to an estimated additional 50-mbsf in-situ stress, and the same measurements were repeated. Two additional samples were consolidated in an odometer, and permeability was measured after each load using a falling-head permeameter (Lambe, 1951).

The lower parts of these holes were logged by personnel from Lamont-Doherty Earth Observatory, Columbia University, during 
Leg 135 using standard downhole logging techniques (Parson, Hawkins, Allan, et al., 1992). Compressional-wave velocity results were smoothed over approximately $0.3-\mathrm{m}$ intervals by using a $15-$ point running average.

\section{RESULTS}

\section{Index Properties}

Index properties (Fig. 2) measured on the sediments overlying basalt show negligible gradients as a function of depth. In a normally consolidated sedimentary section, one expects that density, especially wet-bulk density, will increase as a function of increasing effective stress downhole. Similarly, water content and porosity should decrease as a result of the ongoing consolidation that normally takes place as sedimentation continues.
Commonly, and particularly for results from Sites 834 and 835 , the variation in physical properties observed reflects the lithologies recovered (Parson, Hawkins, Allan, et al., 1992), and the expected downhole trends in physical properties do not occur. Index properties measured on sediments from Site 838 vary more than index properties from the other sites and reflect the more varied lithologies recovered. Nannofossil ooze was the dominant lithology at all sites, but Sites 838 and 839 contain a larger percentage of vitric silt- and sand-sized interbeds within the nannofossil ooze than Sites 834 and 835 .

\section{Compressional- and Shear-wave Velocities}

Compressional- and shear-wave velocities are as much a function of the consolidation state of the sediment as of sediment type. Figure 3 presents a comparison of velocity values measured: (1) in situ using
Water content (\%)

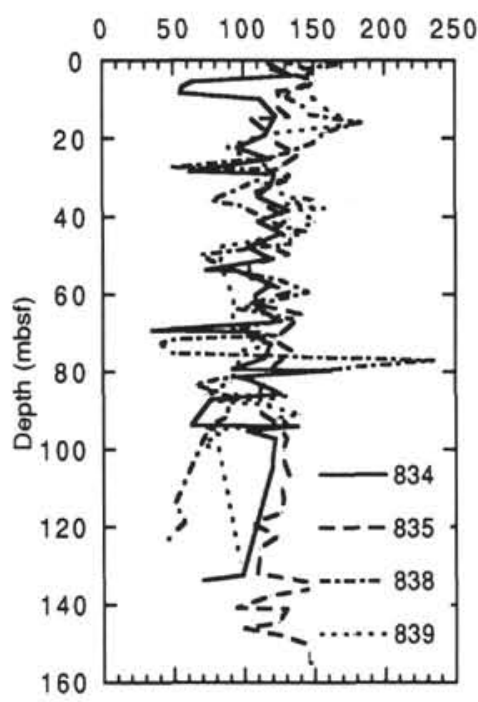

Porosity (\%)

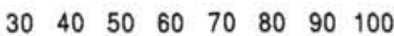

Bulk density $\left(\mathrm{g} / \mathrm{cm}^{3}\right)$

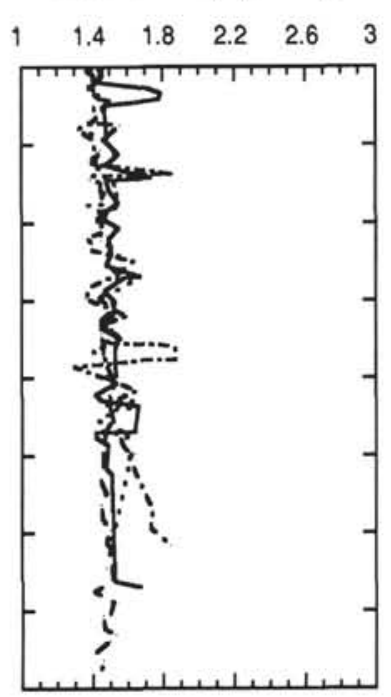

Grain density $\left(\mathrm{g} / \mathrm{cm}^{3}\right)$
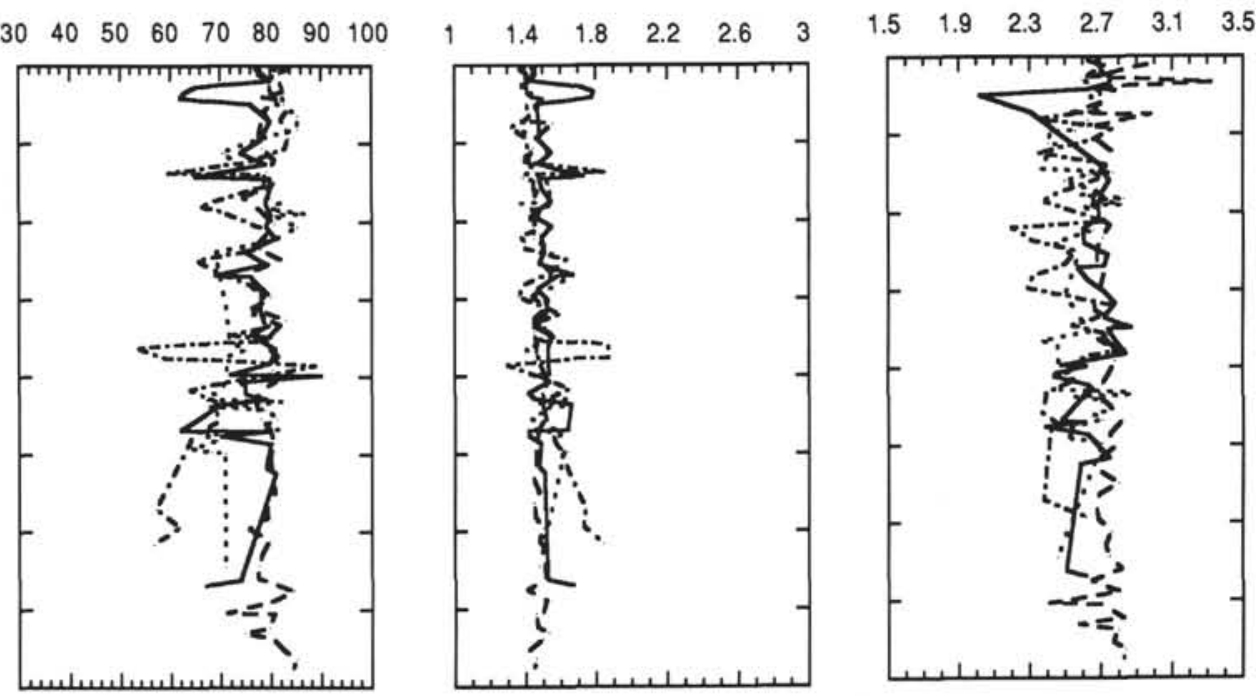

Figure 2. Shipboard-measured index properties of samples from Sites 834, 835, 838, and 839. These properties display little change with depth.

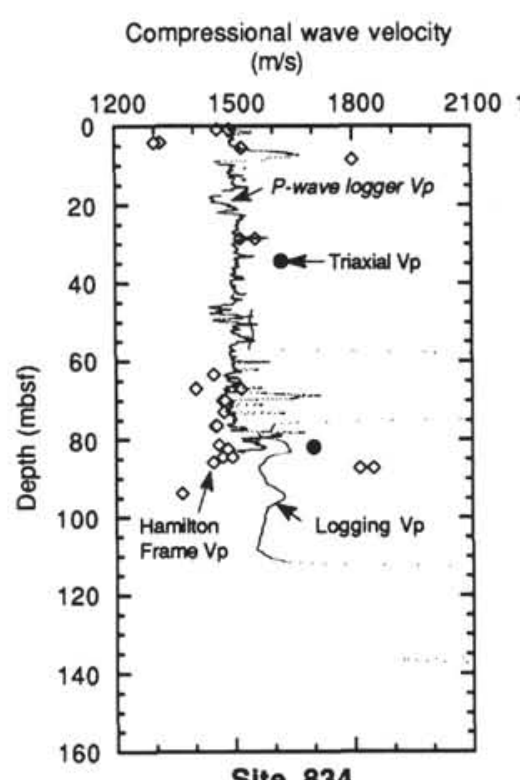

Compressional wave velocity $(\mathrm{m} / \mathrm{s})$

Compressional wave velocity (m/s)
Compressional wave velocity $(\mathrm{m} / \mathrm{s})$

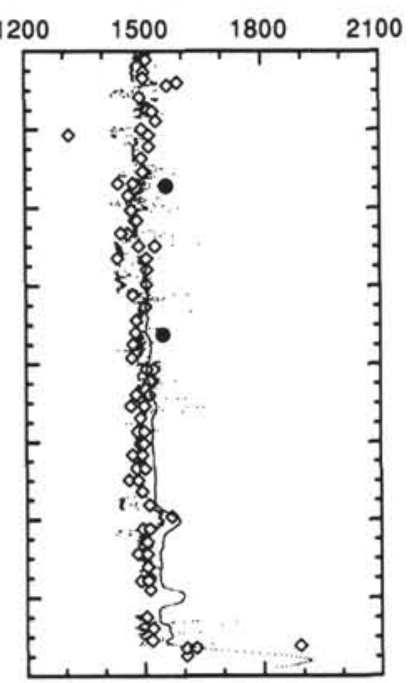

Site 835

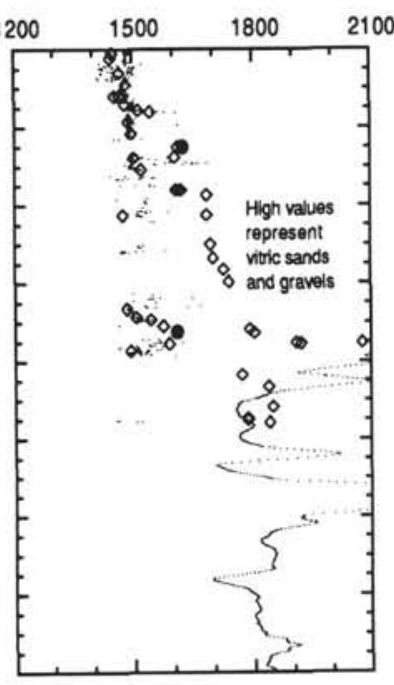

Site 838

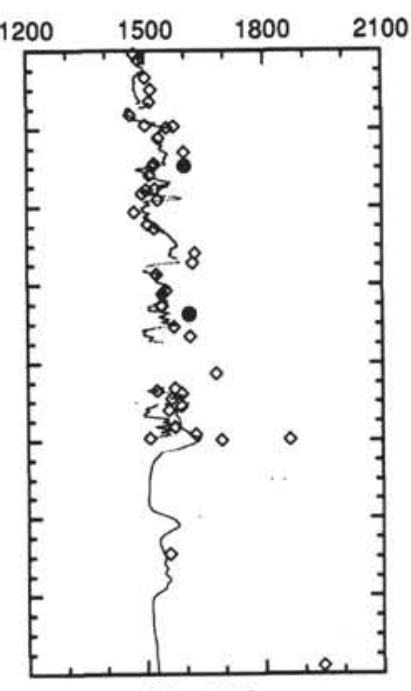

Site 839

Figure 3. Compressional-wave velocities measured on samples from Sites $834,835,838$, and 839 . $P$-wave logger data, obtained from the upper unconsolidated sediments, can be distinguished by position on the graphs from the downhole-logging data that were obtained from the lower parts of the holes (see Site 834). Discrete measurements of samples using the Hamilton Frame device on board are represented by open diamonds. Measurements made under estimated in-situ pressures and $50 \mathrm{~m}$ below estimated in-situ pressures in the triaxial cell are represented by solid circles. 
downhole-logging techniques, (2) on undisturbed sediments still in the core liner using the $P$-wave logger, (3) on discrete samples removed from the core liner using the standard shipboard compressional-wave transducers mounted in the Hamilton Frame, and (4) under estimated in-situ pressures in the triaxial consolidation system.

\section{Sites 834 and 835}

At Sites 834 and 835 , neither $P$-wave logger measurements nor the laboratory measurements made on discrete samples show any appreciable increase with depth of recovery. The variation observed in the laboratory-measured samples may be the result of inadvertent weighting because an effort was made to sample each lithology; however, the $P$-wave logger measures compressional-wave velocities downcore indiscriminately and averages over small intervals. The downhole-logging results from Site 834 were obtained from too great a depth to make valid comparisons with the $P$-wave logger data; however, at Site 835 , downhole logging began at $52 \mathrm{~m}$ below the seafloor (mbsf), and the data showed only a slight increase between 55 and 100 mbsf. In contrast, measurements of both compressionaland shear-wave velocity made on sediments from Sites 834 and 835 during the process of consolidation to an estimated in-situ pressure in the triaxial cell (Fig. 4) show steadily increasing values of velocity with estimated depth. Thus, under steadily increasing pressures in the laboratory, the sediments do consolidate and display the expected trend of increasing velocity. The compressional-wave velocities plotted in Figure 3 are the values measured after the completion of primary consolidation and are between 71 and $200 \mathrm{~m} / \mathrm{s}(5 \%$ and $13 \%)$ higher than either the $P$-wave logger values or the laboratory measurements made at ambient pressures.

\section{Sites 838 and 839}

The results from Site 838 show an increase with increasing depth of laboratory-measured, compressional-wave velocities measured using the Hamilton Frame device. This trend of increasing velocity between 30 and $70 \mathrm{mbsf}$ reflects an increase in grain size as the sediments grade from vitric silts to sands rather than consolidation of the sediments (Parson, Hawkins, Allan, et al., 1992). The $P$-wave logger velocity results from Site 838 show numerous excursions from the mean and numerous gaps in the data caused by voids within the core liner but little increase in velocity overall through the upper $75 \mathrm{~m}$. The logging results, available only below 72 mbsf, show high velocities between 75 and 80 mbsf, reflecting the presence of gravels. Below 85 mbsf, compressional-wave velocities are about $1800 \mathrm{~m} / \mathrm{s}$, similar to laboratory measurements made at ambient pressures. Again, this is probably a reflection of grain size and lithology and not the consolidation state of the sediments. Measurements of samples recovered from 34 and 72 mbsf, made under estimated in-situ stresses in the triaxial system, are about $1600 \mathrm{~m} / \mathrm{s}$ at the two sampling locations. These samples were nannofossil oozes, and the velocities measured in the triaxial cell were higher by about $100 \mathrm{~m} / \mathrm{s}$ than the measurements made at ambient pressures of similar lithologies.

Compressional-wave velocities measured at ambient laboratory pressures agree well with the $P$-wave logger velocities and show only a slight increase over the $100 \mathrm{~m}$ of sediment. Compressional-wave velocities measured in the triaxial system at an estimated pressure corresponding to 74 and 135 mbsf are significantly higher than those of the downhole tools and $P$-wave logger, indicating that the sediments do consolidate in the laboratory but are not completely consolidated in situ.

Estimated in-situ, shear-wave velocities measured in the triaxial system are presented in Table 1. Shear-wave velocity was not measured on board the JOIDES Resolution, so no comparison can be made with estimated in-situ shear velocity. Thus, the triaxial shear-wave results may not reflect in-situ values. If, in fact, the sediments in situ are not consolidating normally, as the index and compressional-wave velocity results suggest, then the in-situ, shear-wave velocities may be significantly lower than the measured results reported here.

\section{Permeability}

Permeability results are presented in Figure 5 as a function of effective stress and are reported in Table 1. Permeability coefficients for sediments measured range from $1.4 \times 10^{-4} \mathrm{~cm} / \mathrm{s}$ for vitric sands recovered in Hole 839A to values on the order of $1 \times 10^{-6}$ to $5 \times 10^{-7}$ $\mathrm{cm} / \mathrm{s}$ for nannofossil oozes and $4 \times 10^{-8} \mathrm{~cm} / \mathrm{s}$ and lower for highly clayey nannofossil oozes.

These measured permeability coefficients vary over several orders of magnitude. The values measured on vitric ash samples from Site 839 represent a high permeability, comparable to a sand-sized sediment. The remainder of the Leg 135 sediments have permeability coefficients that vary depending on the amount of clay present. Samples with even a small percentage of clay material tend to have permeability coefficients similar to samples of pure clay (Lavoie and Bryant, 1993) because the permeability is controlled by the smallest grain size. Several of the nannofossil oozes that are highly clayey and friable (samples from Sites 834 and 835 ) have very low permeabilities, lower than those measured on red clays from Site 532 (northwest Pacific; Lavoie and Bryant, 1993).

\section{DISCUSSION}

Sediments in the Lau backarc basin display none of the expected trends in physical and acoustic properties as a function of depth. We have shown, by measuring both compressional- and shear-wave velocities in a controlled triaxial setting, that the sediments do consolidate and that the velocities measured after consolidation to estimated in-situ pressures are higher than those measured in situ; therefore, we feel that the sediments are not completely consolidated in situ. A number of reasons related to methodology may contribute to these results. Far fewer triaxial compressional-wave velocities than downhole-logging or $P$-wave logger velocities were measured simply because few whole rounds were available for destructive testing. In addition, the size of the samples on which compressional-wave velocity was measured in the triaxial cell was smaller than the average logging samples. Moreover, measurement by logging techniques encompass all inhomogeneities that are present, including cracks, whereas the smaller samples used in the laboratory tended to be fairly competent. Thus, this difference in sample size and possibly sample quality would tend to result in higher laboratory values than those measured in situ. However, lower laboratory compressional-wave velocities might be expected as a result of any disturbance that might have occurred during the coring or handling of the samples.

Although problems related to sampling and sample size may have affected our results, we feel that the influence of geologic processes operating in the region is far more likely. These possible processes include (1) high sedimentation rates that could prevent the sediments from dewatering and consolidating normally, and (2) fluid lost during the consolidation process that could be rapidly replaced by fluids circulating through the system convectively.

\section{Sedimentation Rates}

In the Lau Basin, early sedimentation rates during deposition of the volcaniclastic sediments were extremely high. For example, at Site $834,106 \mathrm{~m}$ of sediment was deposited during $5.5 \mathrm{~m} . \mathrm{y}$. The total stress $(\sigma)$ at the bottom of the sediment column is the sum of the pore fluid stress $(\mu)$ and the effective stress $\left(\sigma^{\prime}\right.$; that portion of the total stress borne by the sediment). Assuming an average pore-fluid density of $1.025 \mathrm{~g} / \mathrm{cm}^{3}$ and a representative sediment density of $1.46 \mathrm{~g} / \mathrm{cm}^{3}$, the total stress at the bottom of the sediment column is about 2582 $\mathrm{kPa}$, of which $1517 \mathrm{kPa}$ will be borne by the sediments under normal consolidation conditions. If the sediments are unable to dewater fast 
135-838 A-8H-4
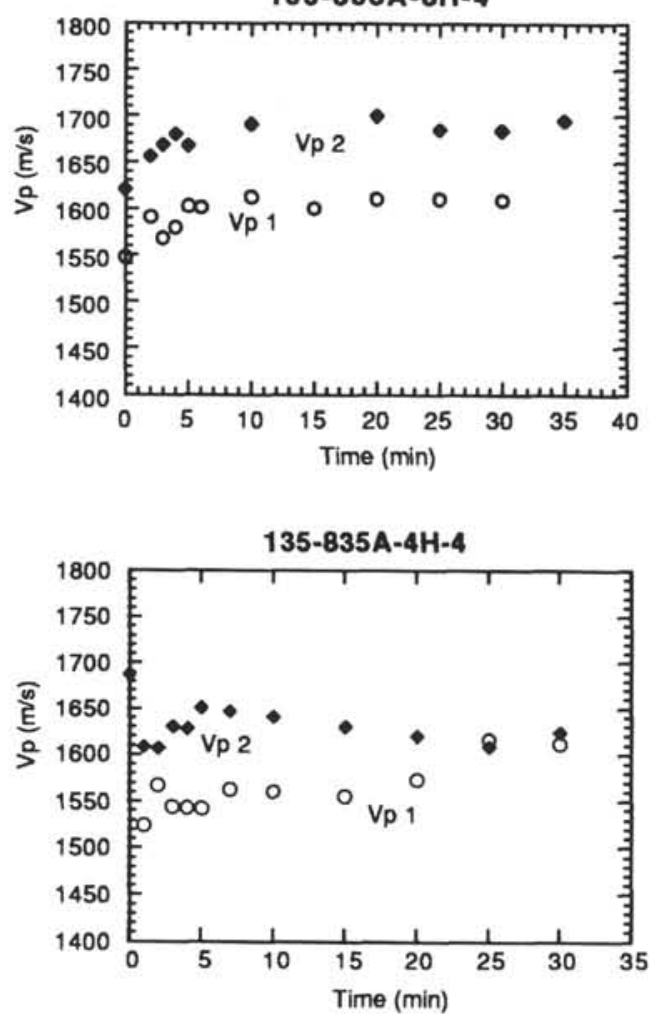

135-838A-8H-4

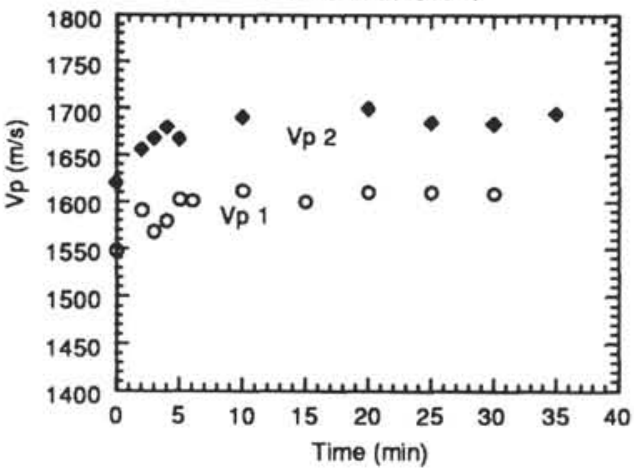

135-839A-4H-4

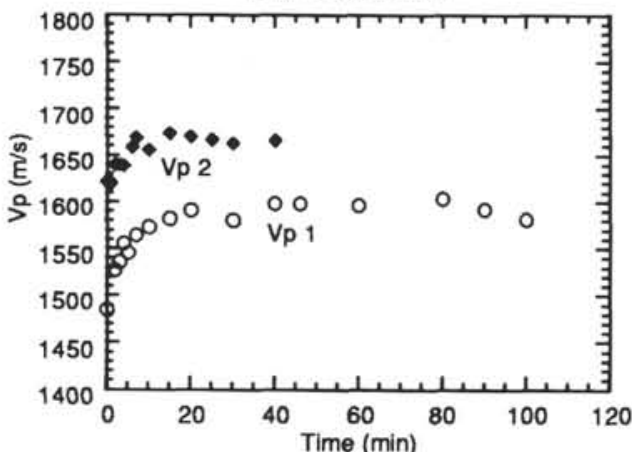

135-834A-4H-4

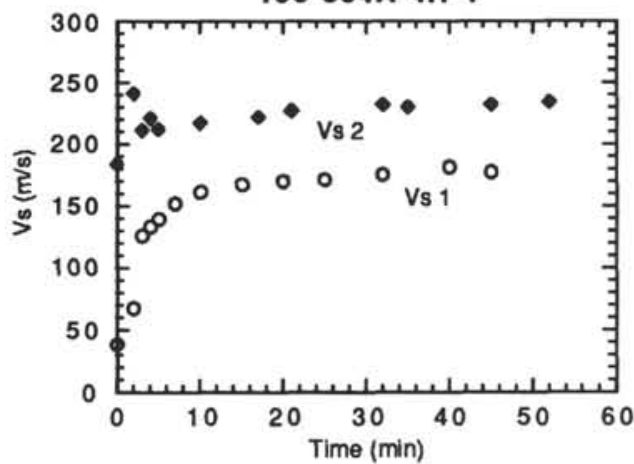

135-835A-4H-2

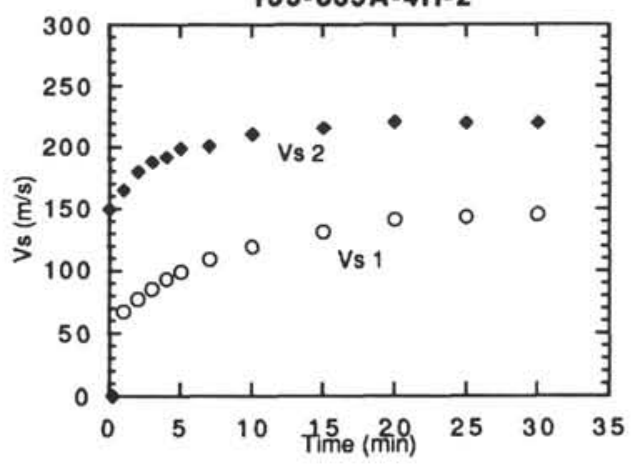

135-838A-8H-4

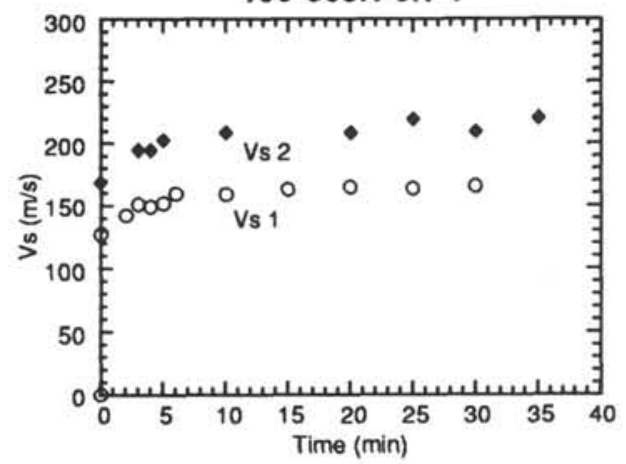

135-839A-4H-4

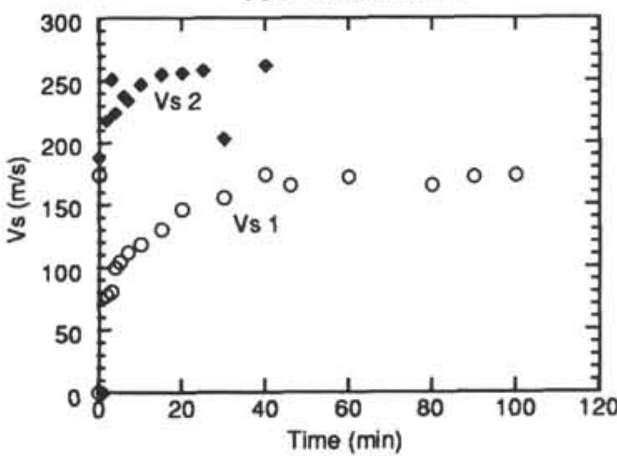

Figure 4. Compressional- and shear-wave velocities measured in a triaxial cell under increasing effective stress. $V_{p} 1$ and $V_{s} I$ represent results under estimated in-situ effective stress, and $V_{p} 2$ and $V_{s} 2$ represent results under a stress estimated to be $50 \mathrm{~m}$ below estimated in-situ stress. 


\section{Effective stress}

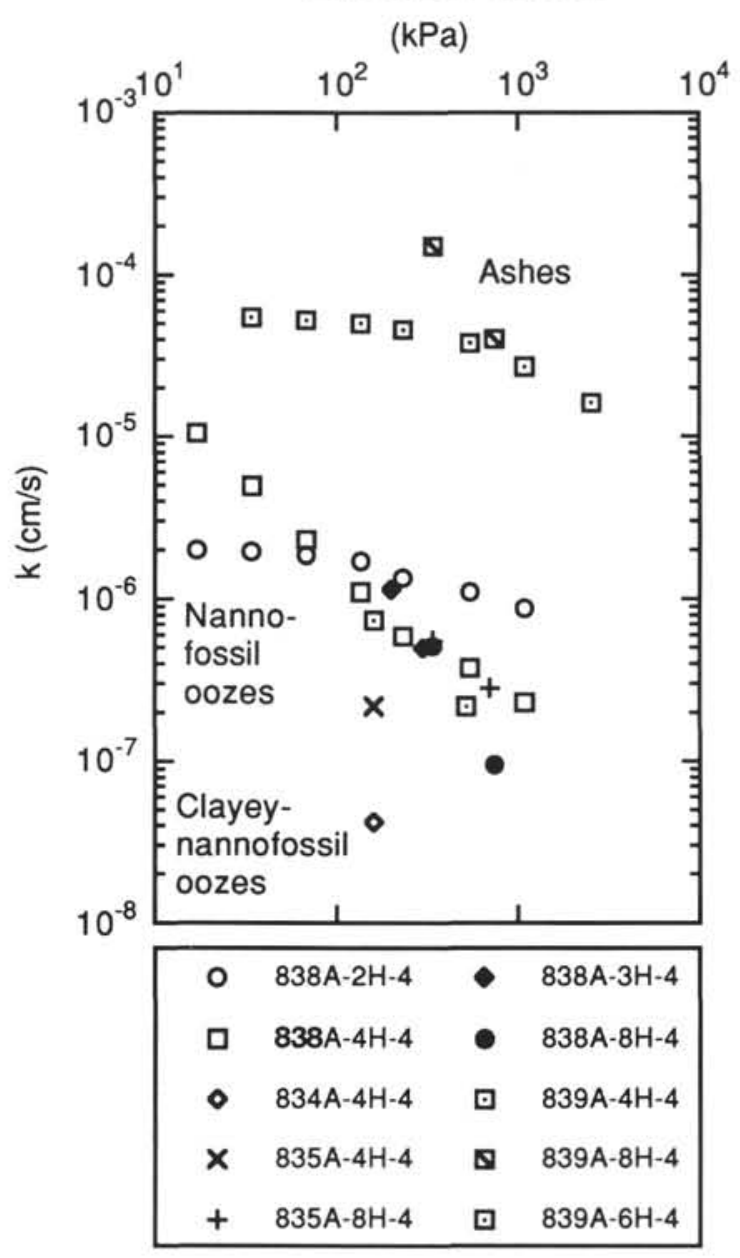

Figure 5. Permeability coefficients measured on whole-round samples from Sites $834,835,838$, and 839 in the Lau Basin. These results were obtained using either a triaxial cell or an incremental loading odometer.

enough to keep up with increasing sedimentation, then excess pore pressures build up within the sediments. At this point, the water will carry increasing portions of the overburden stress, whereas the sediments will carry less than their calculated share of the overburden and so are considered underconsolidated. This condition commonly occurs where low-permeable sediments such as clays overlie more permeable sediments, thus preventing the deeper sediments from dewatering. At the Lau Basin sites, the overlying nannofossil oozes are of lower permeability than the underlying vitric-silt and sandy-ash layers. The nannofossil oozes may function as a leaky aquitard or a semipermeable cap.

To estimate how much fluid can move through the sediments at these four sites, Figure 6 presents a simple model of these sites in which the sediments can be categorized as clayey nannofossil ooze, clayey nannofossil ooze with numerous interbeds of vitric silts and sands, and thick volcanic silts and sands with no clay or nannofossil ooze. A representative permeability $(k)$, the ease with which a fluid can flow through the sediment, was assigned to each sediment type based on the values measured in the laboratory on similar sediments. At Site 834 , fluid could travel through the upper $43 \mathrm{~m}$ of clayey nannofossil ooze $\left(k=4 \times 10^{-8} \mathrm{~cm} / \mathrm{s}\right)$ at the rate of $3.46 \times 10^{-5} \mathrm{~m} /$ day; that is, it would take $3456 \mathrm{yr}$ for a slug of fluid to travel vertically through those $43 \mathrm{~m}$. Similarly, it would take $203 \mathrm{yr}$ for that slug of fluid to travel through the $32 \mathrm{~m}$ of clayey nannofossil ooze with silts and sands $\left(k=5 \times 10^{-7} \mathrm{~cm} / \mathrm{s}\right)$, and only $0.66 \mathrm{yr}$ to travel through the $31 \mathrm{~m}$ of volcanic silts and sands $\left(k=1.5 \times 10^{-4} \mathrm{~cm} / \mathrm{s}\right)$.

In a marine environment where the sedimentary sequence is composed of layered beds of varying heterogeneity, it is possible to look at the differences between lateral and vertical permeability using the following formulas, where $k_{x}$ represents permeability in the horizontal direction and $k_{y}$ represents permeability in the vertical direction for the entire sequence (Domenico and Schwartz, 1990):

$$
\begin{gathered}
k_{x}=\sum\left(z_{i} k_{i}\right) / \sum z_{i} \text { and } \\
k_{y}=\sum z_{i} / \sum\left(z_{i} / k_{i}\right),
\end{gathered}
$$

where $z$ represents the thickness of the layer. Using the values assigned to the layers at Site 834 , the equivalent horizontal permeability is 4.4 $\times 10^{-5} \mathrm{~cm} / \mathrm{s}$, whereas the equivalent vertical permeability is $9.3 \times 10^{-8}$ $\mathrm{cm} / \mathrm{s}$. These values suggest that horizontal flow may dominate this system. However, the upper $43 \mathrm{~m}$ of nannofossil ooze is not sufficiently impermeable to form an aquitard. Similar calculations from Sites 835 , 838 , and 839 suggest that the overlying nannofossil oozes are not functioning as aquitards; rather, the clayey nannofossil oozes have the capability of allowing fluids to pass through the sediment column.

The volume of water lost to consolidation that would have to be replaced by fluid circulation at Site 834 can be estimated using the following logic. If we assume a $1 \mathrm{~m} \times 1 \mathrm{~m} \times 106 \mathrm{~m}$ section of sediment equal to $106 \mathrm{~m}^{3}$ of sediment with a representative porosity of $75 \%$, the volume of water within that column equals $79.5 \mathrm{~m}^{3}$. Hamilton (1976) predicts that calcareous sediments will undergo a $10 \%$ reduction in porosity over $100 \mathrm{~m}$ of sediment under normally consolidating conditions. At Site 834 , this would result in $8 \mathrm{~m}^{3}$ of fluid lost to consolidation over the $5.5 \mathrm{~m}$.y. during which the sediments were deposited; therefore, the rate at which fluid would be lost $(Q)$ would be $1.45 \times 10^{-6} \mathrm{~m}^{3} / \mathrm{yr}$. A very small gradient $(i)$ would be required to replace $8 \mathrm{~m}^{3}$ of fluid at this rate. Darcy's equation reads (Lambe, 1951):

$$
\mathrm{Q}=k i A,
$$

where we assume $A$ to be the cross-sectional area through which the fluid must pass. Using a representative permeability of $4 \times 10^{-8} \mathrm{~cm} / \mathrm{s}$ for a nannofossil ooze, the gradient required to pass fluid through the nannofossil ooze at this rate is $1.5 \times 10^{-8}$, and the gradient required to pass fluid through the vitric sands and silts is $9.9 \times 10^{-12}$.

\section{Fluid Circulation}

One of the main driving forces behind fluid circulation is a difference in head caused by differences in pressure and density. However, even in the absence of a hydraulic gradient, the presence of a temperature or heat-flow gradient can cause fluid flow (Freeze and Cherry, 1979). The Lau Basin sites are close to an active spreading ridge, a potential source of heat. Measured heat flow at these sites averaged over the sediment column is relatively low when compared with theoretical heat-flow curves (Fig. 7). At Sites 834, 835, 838, and 839 , heat-flow averages were $51,15,56$, and $15 \mathrm{~mW} / \mathrm{m}^{2}$, respectively (Parson, Hawkins, Allan, et al., 1992), whereas simple lithospheric cooling models predict that heat flow ought to be $150 \mathrm{~mW} / \mathrm{m}^{2}$ or higher (Anderson and Skilbeck, 1981).

In a steady-state, conductive system where heat is lost through lithospheric cooling only, heat flow should be the same throughout the sediment column; however, lithology and fluid circulation can have a large effect. Heat flow in each of the different lithologic units and at multiple depths within the units clearly varies more than can be accounted for by simple conductive cooling (Fig. 6). Heat flow for individual layers was calculated in the same manner as for the entire sediment column. Thermal conductivity measurements were used to calculate thermal resistivity within a particular layer, and the results were integrated over the layer (Parson, Hawkins, Allan, et al., 1992). 
Table 1. Geotechnical properties of samples from Sites 834, 835, 838, and 839 in the Lau Basin.

\begin{tabular}{|c|c|c|c|c|c|c|c|c|c|c|c|c|c|c|}
\hline $\begin{array}{l}\text { Core, section, } \\
\text { interval }(\mathrm{cm})\end{array}$ & $\begin{array}{c}\text { Recovery } \\
\text { depth } \\
\text { (mbsf) }\end{array}$ & $\begin{array}{l}\text { Estimated } \\
\text { depth } \\
\text { (mbsf) }\end{array}$ & $\begin{array}{c}V_{p} \\
\text { (triaxial) } \\
(\mathrm{m} / \mathrm{s})\end{array}$ & $\begin{array}{c}V_{s} \\
\text { (triaxial) } \\
(\mathrm{m} / \mathrm{s})\end{array}$ & $\begin{array}{c}V_{p} \\
\text { (laboratory) } \\
(\mathrm{m} / \mathrm{s})\end{array}$ & $\begin{array}{c}V_{p} \\
\text { (logging) } \\
(\mathrm{m} / \mathrm{s})\end{array}$ & $\begin{array}{c}V_{p} \\
(P \text {-wave } \log ) \\
(\mathrm{m} / \mathrm{s})\end{array}$ & $\begin{array}{c}k \\
(\mathrm{~cm} / \mathrm{s})\end{array}$ & $\begin{array}{c}w \\
(\%)\end{array}$ & $\stackrel{\rho}{\rho}\left(\mathrm{g} / \mathrm{cm}^{3}\right)$ & $\begin{array}{c}n \\
(\%)\end{array}$ & e & $\underset{\left(\mathrm{g} / \mathrm{cm}^{3}\right)}{\mathrm{G}}$ & Lithology \\
\hline $\begin{array}{l}135-834 \mathrm{~A}- \\
\quad 4 \mathrm{H}-4,135-140\end{array}$ & 34.35 & $\begin{array}{l}37.11 \\
70.80\end{array}$ & $\begin{array}{l}1620 \\
1710\end{array}$ & $\begin{array}{l}170 \\
230\end{array}$ & $1500^{a}$ & $1600^{\mathrm{b}}$ & $\begin{array}{l}1500 \\
1500\end{array}$ & $4.18 \times 18^{-8}$ & $\begin{array}{r}103.4 \\
88.7\end{array}$ & $\begin{array}{l}1.44 \\
1.49\end{array}$ & $\begin{array}{l}73 \\
70\end{array}$ & $\begin{array}{l}2.75 \\
2.36\end{array}$ & $\begin{array}{l}2.65 \\
2.66\end{array}$ & Clayey nannofossil ooze \\
\hline \multirow[t]{2}{*}{$9 \mathrm{H}-4,135-140$} & 81.85 & 58.31 & 1700 & 140 & 1500 & 1600 & NA & TS & 134.0 & 1.35 & 78 & 3.49 & 2.59 & \multirow[t]{2}{*}{$\begin{array}{l}\text { Dry friable nannofossil } \\
\text { ooze }\end{array}$} \\
\hline & & 118.65 & - & 160 & - & - & - & - & 108.0 & 1.43 & 75 & 2.93 & 2.69 & \\
\hline \multirow[t]{2}{*}{$\begin{array}{l}135-835 \mathrm{~A}- \\
4 \mathrm{H}-4,135-140\end{array}$} & 34.35 & 37.97 & 1570 & 145 & 1465 & $1525^{\mathrm{c}}$ & 1500 avg. & $2.18 \times 10^{-7}$ & 106.0 & 1.43 & 74 & 2.80 & 2.63 & \multirow[t]{2}{*}{$\begin{array}{l}\text { Vitric glass particles within } \\
\text { clayey nannofossil ooze }\end{array}$} \\
\hline & & 98.12 & 1650 & 220 & - & - & $\begin{array}{l}\text { (variation: } \\
\text { glass) }\end{array}$ & - & 84.0 & 1.52 & 69 & 2.26 & 2.69 & \\
\hline $8 \mathrm{H}-4,135-140$ & 72.35 & $\begin{array}{r}75.42 \\
145.77\end{array}$ & $\begin{array}{l}1550 \\
1575\end{array}$ & $\begin{array}{l}160 \\
240\end{array}$ & $\stackrel{1479}{-}$ & 1520 & $\begin{array}{l}1500 \\
1500\end{array}$ & $\begin{array}{l}5.55 \times 10^{-7} \\
2.82 \times 10^{-7}\end{array}$ & $\begin{array}{l}97.1 \\
90.1\end{array}$ & $\begin{array}{l}1.46 \\
1.49\end{array}$ & $\begin{array}{l}72 \\
70\end{array}$ & $\begin{array}{l}2.54 \\
2.38\end{array}$ & $\begin{array}{l}2.62 \\
2.64\end{array}$ & Friable nannofossil ooze \\
\hline $\begin{array}{l}135-838 \mathrm{~A}- \\
2 \mathrm{H}-4,135-140\end{array}$ & 9.55 & - & - & $75^{\mathrm{d}}$ & 1480 & NA & 1450 & $1.95 \times 10^{-6}$ & 126.9 & 1.39 & 78 & 3.47 & 2.73 & Nannofossil ooze \\
\hline $4 \mathrm{H}-4,135-140$ & 28.55 & $\begin{array}{l}-\overline{60.24} \\
80.55 \\
-\end{array}$ & $\begin{array}{l}1630 \\
\text { NC } \\
-\end{array}$ & $\begin{array}{l}\overline{215} \\
\mathrm{NC}_{99^{\mathrm{d}}}\end{array}$ & $\frac{\overline{1600}}{1 \overline{1520}}$ & $\frac{\overline{N A}}{\overline{N A}}$ & $\begin{array}{l}1500 \\
1500 \\
1500\end{array}$ & $\begin{array}{c}1.14 \times 10^{-6} \\
4.96 \times 10^{-7} \\
1.10 \times 10^{-10}\end{array}$ & $\begin{array}{r}79.6 \\
142.1 \\
128.3 \\
123.6\end{array}$ & $\begin{array}{l}1.52 \\
1.34 \\
1.38 \\
1.39\end{array}$ & $\begin{array}{l}67 \\
79 \\
77 \\
77\end{array}$ & $\begin{array}{l}2.05 \\
3.68 \\
3.40 \\
3.32\end{array}$ & $\begin{array}{l}2.57 \\
2.59 \\
2.65 \\
2.69\end{array}$ & $\begin{array}{l}\text { Nannofossil ooze } \\
\text { Nannofossil ooze }\end{array}$ \\
\hline $8 \mathrm{H}-4,135-140$ & 72.35 & $\begin{array}{r}7 \overline{73.81} \\
134.84\end{array}$ & $\begin{array}{l}1 \overline{1610} \\
1690\end{array}$ & $\begin{array}{l}\overline{160} \\
210\end{array}$ & $\begin{array}{l}1800 \\
-\end{array}$ & $\begin{array}{c}2200-2300 \\
1800^{\mathrm{C}}\end{array}$ & $\begin{array}{l}1 \overline{1500} \\
1500\end{array}$ & $\begin{array}{l}5.08 \times 10^{-7} \\
9.50 \times 10^{-8}\end{array}$ & $\begin{array}{l}77.4 \\
94.7 \\
75.0\end{array}$ & $\begin{array}{l}1.52 \\
1.47 \\
1.56\end{array}$ & $\begin{array}{l}67 \\
72 \\
67\end{array}$ & $\begin{array}{l}1.97 \\
2.51 \\
2.00\end{array}$ & $\begin{array}{l}2.55 \\
2.65 \\
2.67\end{array}$ & $\begin{array}{l}\text { Nannofossil ooze with } \\
\text { vitric sand and gravel }\end{array}$ \\
\hline $\begin{array}{l}135-839 \mathrm{~A}- \\
4 \mathrm{H}-4,135-140\end{array}$ & 29.35 & 38.87 & 1600 & 165 & 1525 & $1525 \mathrm{f}$ & $1525^{8}$ & $7.37 \times 10^{-7}$ & 111.1 & 1.42 & 75 & 2.96 & 2.66 & $\begin{array}{l}\text { Vitric sands with some } \\
\text { nannofossil ooze }\end{array}$ \\
\hline $8 \mathrm{H}-4,135-140$ & 67.35 & $\begin{array}{r}129.87 \\
73.82 \\
151.02\end{array}$ & $\begin{array}{l}1670 \\
\text { TF } \\
1610\end{array}$ & $\begin{array}{r}260 \\
1550 \\
\text { TF }\end{array}$ & $\overline{1550}$ & $\overline{1525}$ & $\overline{1525}$ & $\begin{array}{l}2.18 \times 10^{-7} \\
1.50 \times 10^{-4} \\
3.99 \times 10^{-5}\end{array}$ & $\begin{array}{r}102.1 \\
80.8 \\
77.4\end{array}$ & $\begin{array}{l}1.44 \\
1.47 \\
1.50\end{array}$ & $\begin{array}{l}73 \\
66 \\
65\end{array}$ & $\begin{array}{l}2.65 \\
1.92 \\
1.88\end{array}$ & $\begin{array}{l}2.59 \\
2.38 \\
2.43\end{array}$ & Vitric silt and sand \\
\hline
\end{tabular}

Notes: Abbreviations are as follows: $V_{p}=$ compressional-wave velocity, $V_{s}=$ shear-wave velocity, $k=$ permeability coefficient, $w=$ water content, $\rho=$ wet-bulk density, $n=$ porosity, $\mathrm{e}=$ void ratio, $\mathrm{G}=$ specific gravity, $\mathrm{NA}=$ not available, avg. $=$ average, $\mathrm{NC}=$ no change, $\mathrm{TS}=$ too slow to measure, and $\mathrm{TF}=$ too fast to measure.

a Average value, $0-80 \mathrm{mbsf}$.

b Average value, $80-100$ mbsf

c Average value, $50-75$ mbsf.

d Measurement obtained with Hamilton Frame device.

c Average value at 95 mbsf.

Average value, $150-160$ mbsf.

$g$ Average value, no gradient.

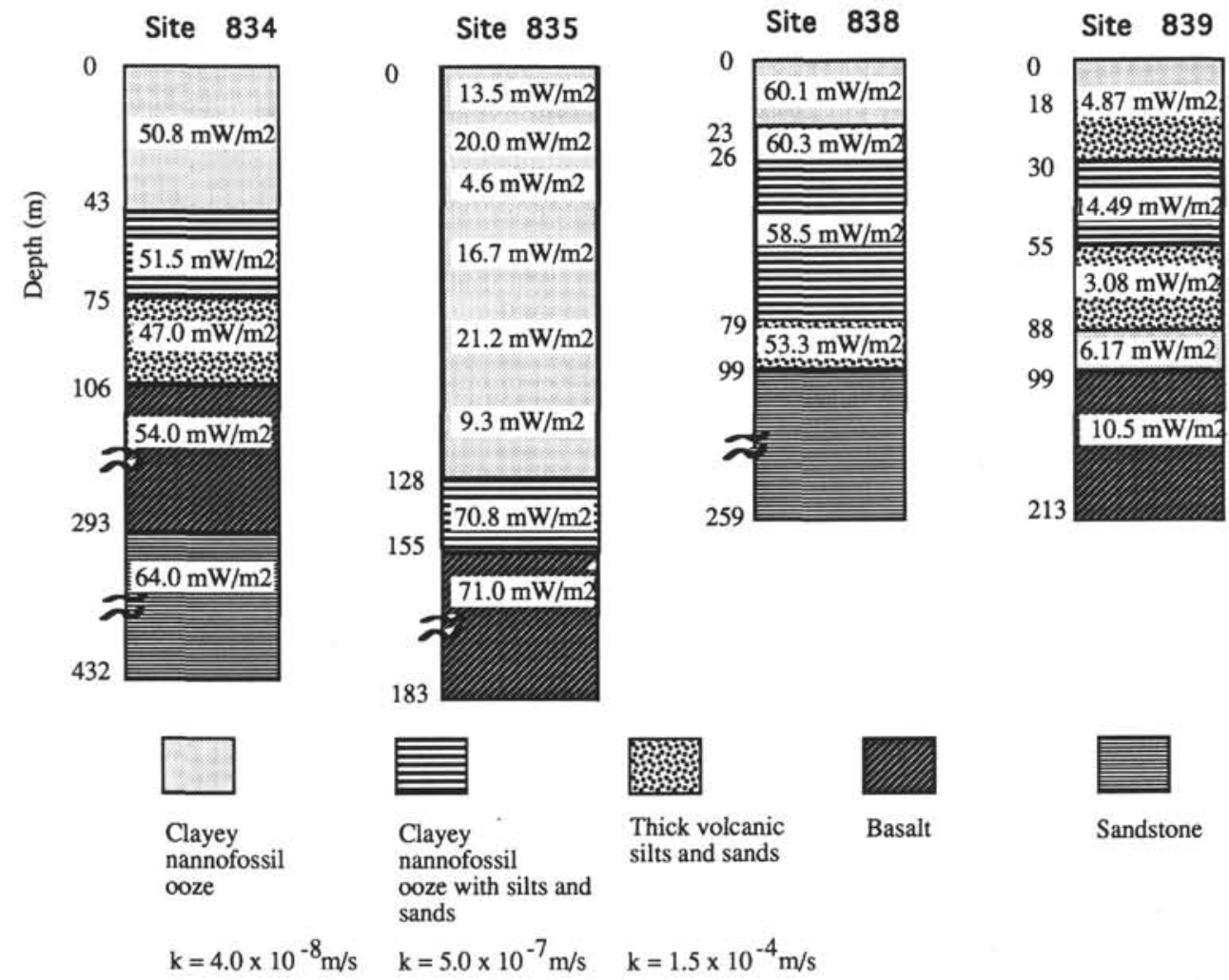

Figure 6. Schematic representation of a model for fluid flow through simplified sections representing Sites 834,835 , 838 , and 839 (not to scale). 


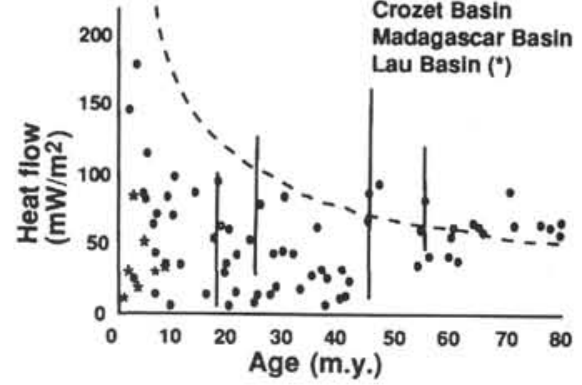

Figure 7. Heat flow vs. crustal age. The dashed line represents heat flow calculated from simple lithospheric cooling. The small circles represent measured data from the Crozet and Madagascar basins (after Anderson and Skilbeck, 1981). The Lau Basin data points are represented by asterisks.

When the resulting thermal resistance is plotted vs. the temperature measurements from the layer, the slope of the regression line is equal to the heat flow within that layer.

The calculated heat flow for the various layers and within some of the layers is presented in Figure 6. At Site 834, for example, the heat flow within the sediment column is roughly $50 \mathrm{~mW} / \mathrm{m}^{2}$. In the overlying nannofossil oozes, heat-flow values are roughly $50 \mathrm{~mW} / \mathrm{m}^{2}$; in the volcanic silts and sands at $75 \mathrm{mbsf}$, heat flow is $47 \mathrm{~mW} / \mathrm{m}^{2}$; in the basalt sill at $106 \mathrm{mbsf}$, heat flow is $54 \mathrm{~mW} / \mathrm{m}^{2}$; and in the underlying sandstones at $106 \mathrm{mbsf}$, heat flow is $64 \mathrm{~mW} / \mathrm{m}^{2}$. This variation in heat-flow values suggests that some of the expected heat is being removed from the sediment column. One possible place is at the boundary between the sandstones and the basalt. Another possible place for heat removal may be within the volcanic silts and sands, particularly if this layer dominates the horizontal component of fluid flow within the system. Similarly, at Site 835, heat varies somewhat throughout the nannofossil oozes, but a significant difference in heat flow occurs between near-surface nannofossil oozes and the underlying interbedded nannofossil oozes and silt and sand. The silt and sand oozes, and the underlying basalt, have heat flow of about $70 \mathrm{~mW} / \mathrm{m}^{2}$. Therefore, at Site 835 , some of the heat may be removed along the boundary between the nannofossil oozes and the silt and sand nannofossil oozes. At Site 838, not enough data were obtained to determine if, or how much, heat is being lost between the sediment and sandstones; this site did not penetrate basalt. Site 839 has very low heat-flow values throughout the sediment and the underlying basalt section, particularly within the volcanic silts and sands; the whole system must be losing heat somewhere.

Active convective fluid circulation is a possible mechanism for removing heat. If the fluids were traveling upward from the heat source, heat flow should be high, possibly as high as theoretical heat-flow predictions (Fig. 7). If, however, these sites are in downwelling zones of fluid circulation, then heat flow would be low, reflecting the presence of cold seawater. An abrupt or significant change in heat flow from one section of the sediment column to another may indicate lateral fluid flow (Domenico and Schwartz, 1990).

In general, the chemistry of pore fluids measured at these sites indicates (1) that the primary reaction taking place in the pore fluids is the alteration of either the volcanogenic sediments or the underlying basalt (or both), and (2) water with a seawater signature is being introduced into the sediment column, either by downwelling through the entire sediment column or laterally along the most permeable sediment layers (Parson, Hawkins, Allan, et al., 1992). Because the organic content of these sediments is low and the organic matter present is refractory, diagenetic reactions resulting from organic carbon decomposition, and the associated changes in pore-water chemistry, do not occur.

At Site 834 the dissolved-calcium profile increases steadily with depth to the datum at about $100 \mathrm{mbsf}$, suggesting lateral advection of bottom water below 80 mbsf, either with the bottom sediment section along the sediment/basalt interface or within the uppermost basalt layer (Fig. 8; Parson, Hawkins, Allan, et al., 1992). Similarly, at Site 835 the dissolved calcium profile steadily increases with depth to about $110 \mathrm{mbsf}$ and then decreases. This suggests lateral injection of bottom water within the bottom sediment section along the sediment/basalt interface or within the uppermost basalt layer. At Site 839, a low gradient of dissolved calcium and magnesium suggests that the fluid circulation system includes exchange with the underlying basement. A trend in dissolved calcium with depth does not appear to exist. This is consistent with downwelling of bottom water through the entire sediment column; however, it is possible that lateral advection of bottom water is occurring through the two major vitric silt and sand sequences and that diffusive mixing is occurring between adjacent sediment sections, resulting in no appreciable gradient.
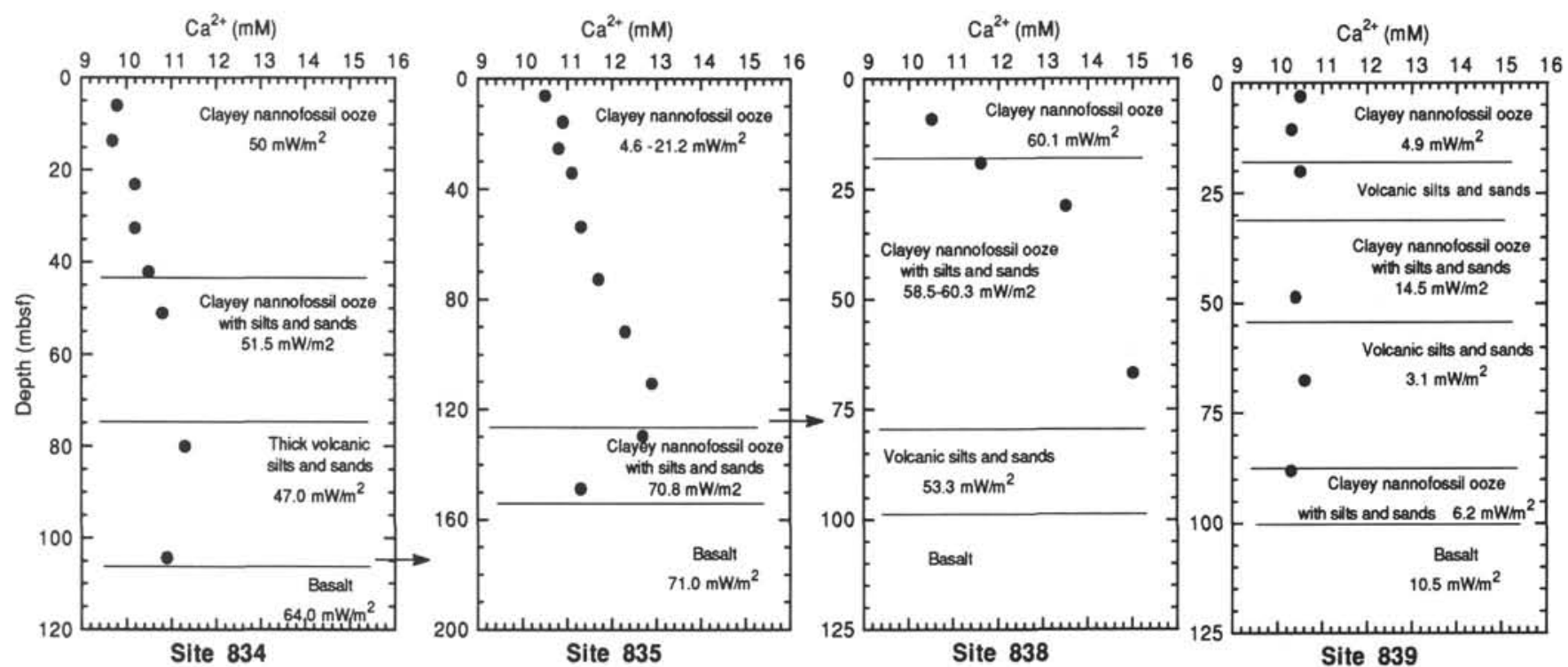

Figure 8. Profiles of dissolved pore-fluid calcium from the Lau backarc sites. The decrease in dissolved calcium from Sites 834 and 835 may have resulted from diagenetic reactions or dilution by fluid circulation. 


\section{SUMMARY AND CONCLUSIONS}

The volume of fluid required to (1) dissipate the excess heat expected but not measured and (2) prevent the sediments from consolidating normally in the Lau backarc sites is very small, about $8 \mathrm{~m}^{3}$ at Site 834 . Very small gradients are required to replace this amount of fluid during the 5.5 m.y. of sediment deposition.

In general, sites of downwelling are much more diffuse and cooler than sites of upwelling. Site 839 is probably a downwelling site, but the remaining three sites are possibly located in a zone of lateral fluid flow within a large-scale, convective circulation cell. Although the overlying nannofossil oozes are not sufficiently impermeable to prevent vertical fluid flow, the very permeable vitric silts and sands may act as horizontal conduits for this flow.

The lack of expected gradients in index properties and compressional-wave velocities may result from the inability of the sediment to consolidate in a zone of active fluid circulation where water lost to consolidation is immediately replaced.

\section{ACKNOWLEDGMENTS}

The authors thank Drs. Angela Davis and James Bennell of University College, Menai Bridge, North Wales, for making their triaxial laboratory and expertise available to us. We also thank the Leg 135 Scientific Party for making their data available to us and Denise Kennedy of the U.S. Naval Research Laboratory for patiently running laboratory analyses. This paper was greatly improved as a result of discussions with Dr. H.A. Pittenger of the Naval Research Laboratory. This project was supported by the Naval Research Laboratory, DoD Program Element $0601153 \mathrm{~N}$.

\section{REFERENCES}

Anderson, R.N., and Skilbeck, J.N., 1981. Oceanic heat flow. In Emiliani, C. (Ed.), The Sea (Vol. 7): The Oceanic Lithosphere: New York (Wiley), 489-524.

Domenico, P.A., and Schwartz, F.W., 1990. Physical and Chemical Hydrogeology: New York (Wiley).

Freeze, R.A., and Cherry, J.A., 1979. Groundwater: Englewood Cliffs, NJ (Prentice-Hall).

Hamilton, E.L., 1976. Variations of density and porosity with depth in deep-sea sediments. I. Sediment. Petrol., 46:280-300.

Lambe, T.W., 1951. Soil Testing for Engineers: New York (Wiley).

Lavoie, D.L., and Bryant, W.R., 1993. Permeability characteristics of continental slope and deep water carbonates from a microfabric perspective. In Rezak, R., and Lavoie, D. (Eds.), Carbonate Microfabrics: Heidelberg (Springer-Verlag).

Louden, K.E., and Wright, J.A., 1988. Marine heat flow data: a new compilation of observations and brief review of its analysis. $\ln$ Wright, J.A., Louden, K.E., and Moore, J.R. (Eds.), CRC Handbook of Seafloor Heat Flow: Boca Raton. FL (CRC Press).

Parson, L., Hawkins, J., Allan, J., et al., 1992. Proc. ODP, Init. Repts., 135: College Station, TX (Ocean Drilling Program).

Abbreviations for names of organizations and publication titles in ODP reference lists follow the style given in Chemical Abstracts Service Source Index (published by American Chemical Society).

Date of initial receipt: 30 June 1992

Date of acceptance: 3 August 1993

Ms 135SR-148 